\title{
CREEP OF ICE CONTAINING DISPERSED FINE SAND
}

\author{
By Roger LeB. Hooke, Brian B. Dahlin and Mighael T. Kauper \\ (Department of Geology and Geophysics, University of Minnesota, Minneapolis, Minnesota \\ 55455 , U.S.A.)
}

\begin{abstract}
Cylindrical samples of ice with o.o to 0.35 volume fraction fine sand were tested in unconfined uniaxial compression at stresses between $5 \cdot 3$ and 6.4 bar and at temperatures between $-7 \cdot 4$ and $-9.4{ }^{\circ} \mathrm{C}$. Secondary creep rates were obtained from the slope of the total strain vs. time curve and were normalized to 5.6 bar and $-9.1^{\circ} \mathrm{C}$. Creep rates in ice with low sand concentrations were in some cases higher and in other cases lower than in clean ice. However at higher sand concentrations the creep rate decreases exponentially with increasing volume fraction sand. The latter results are in general agreement with theories developed to explain dispersion hardening of metals, and suggest that each sand grain is surrounded by a tangled network of secondary dislocations which impede passage of primary glide dislocations.
\end{abstract}

RÉsumé. Fluage de la glace contenant un sable fin en dispersion. On a testé des échantillons cylindriques de glace contenant $\mathrm{o}, \mathrm{o}$ à $\mathrm{o}, 35$ fois son volume de sable fin en les soumettant à une compression uniaxiale comprise entre 5,3 et 6,4 bar et à une température comprise entre $-7,4$ et $-9,4{ }^{\circ} \mathrm{C}$. La vitesse de fluage secondaire fut obtenue à partir de la pente de la courbe donnant la déformation totale en fonction du temps et fut normalisée à donner la vitesse à 5,6 bar et $-9,1^{\circ} \mathrm{C}$. Les vitesses de fluage dans la glace à faible concentration de sable furent dans quelques cas plus grandes et dans les autres plus faibles que dans la glace propre. Cependant, aux plus grandes concentrations en sable la vitesse de fluage décroît exponentiellement par rapport au volume croissant d'inclusion sableuse. Les derniers résultats sont généralement conformes aux théories développées pour expliquer le durcissement des métaux par dispersion et suggère que chaque grain de sable est entouré d'un réseau enchevêtré de dislocations cristallines secondaires qui empêchent le passage des dislocations primaires de glissement.

Zusammenfassung. Kriechen von Eis, das mit Feinsand durchsetzt ist. Zylindrische Eisproben mit einem Volumenanteil von o,o bis o, 35 an Feinsand wurden unter unbegrenztem einachsigem Druck bei Spannungen zwischen 5,3 und 6,4 bar und Temperaturen zwischen $-7,4$ und $-9,4^{\circ} \mathrm{C}$ untersucht. Sekundäre Kriechgeschwindigkeiten ergaben sich aus der Steigung des Gesamtspannungs-Zeit-Diagrammes; sie wurden auf 5,6 bar und $-9, \mathrm{I}^{\circ} \mathrm{C}$ normiert. Die Kriechgeschwindigkeiten in Eis mit geringerer Sandkonzentration waren teils höher teils niedriger als in reinem Eis. Doch nimmt die Kriechgeschwindigkeit bei höheren Sandkonzentrationen exponentiell mit wachsendem Volumenanteil ab. Die letzteren Ergebnisse stimmen generell mit Theorien überein, die zur Erklärung der Dispersionshärtung von Metallen entwickelt wurden; sie lassen vermuten, dass jedes Sandkorn von einem verknüpften Netzwerk von sekundären Versetzungen umgeben ist, das den Durchgang primärer Gleitversetzungen behindert.

\section{INTRODUCTION}

At the base of an ice sheet there is generally a layer of dirty ice several meters in thickness (Hansen and Langway, 1966) which contains 0.000 o4 to o.6 volume fraction debris (Hooke, 1970, p. 306). The rheological properties of such ice have not been investigated at the relatively low deviatoric stress levels found in glaciers.

\section{Procedure}

The present experiments were conducted in uniaxial compression with the use of the apparatus shown in Figure I. Samples were immersed in a bath of 2-2-4 trimethyl pentane (iso-octane) in which ice is insoluble. The bath temperature was controlled with a "Neslab" circulating bath and "Neslab" PBC-2 bath cooler, and generally fluctuated less than 0.2 deg during a run (Table I). At the temperatures used, increasing the temperature by 0.1 deg will increase the creep rate about $\mathrm{I} \%$.

Deformation measurements were made with a drum micrometer (Fig. I) which could be read directly to Io $\mu \mathrm{m}$ and interpolated to I $\mu \mathrm{m}$. When the micrometer touched the insulated plate shown in Figure I, a small current passed between the two and activated a Schmitt trigger (Schmitt, 1938) which caused an ammeter to read full scale. With this system, micrometer readings were reproducible to $\pm 2 \mu \mathrm{m}$. A movement of $2 \mu \mathrm{m}$ at the micrometer corresponded to compression of the sample of about $0.4 \mu \mathrm{m}$. However, because the aluminum frame 


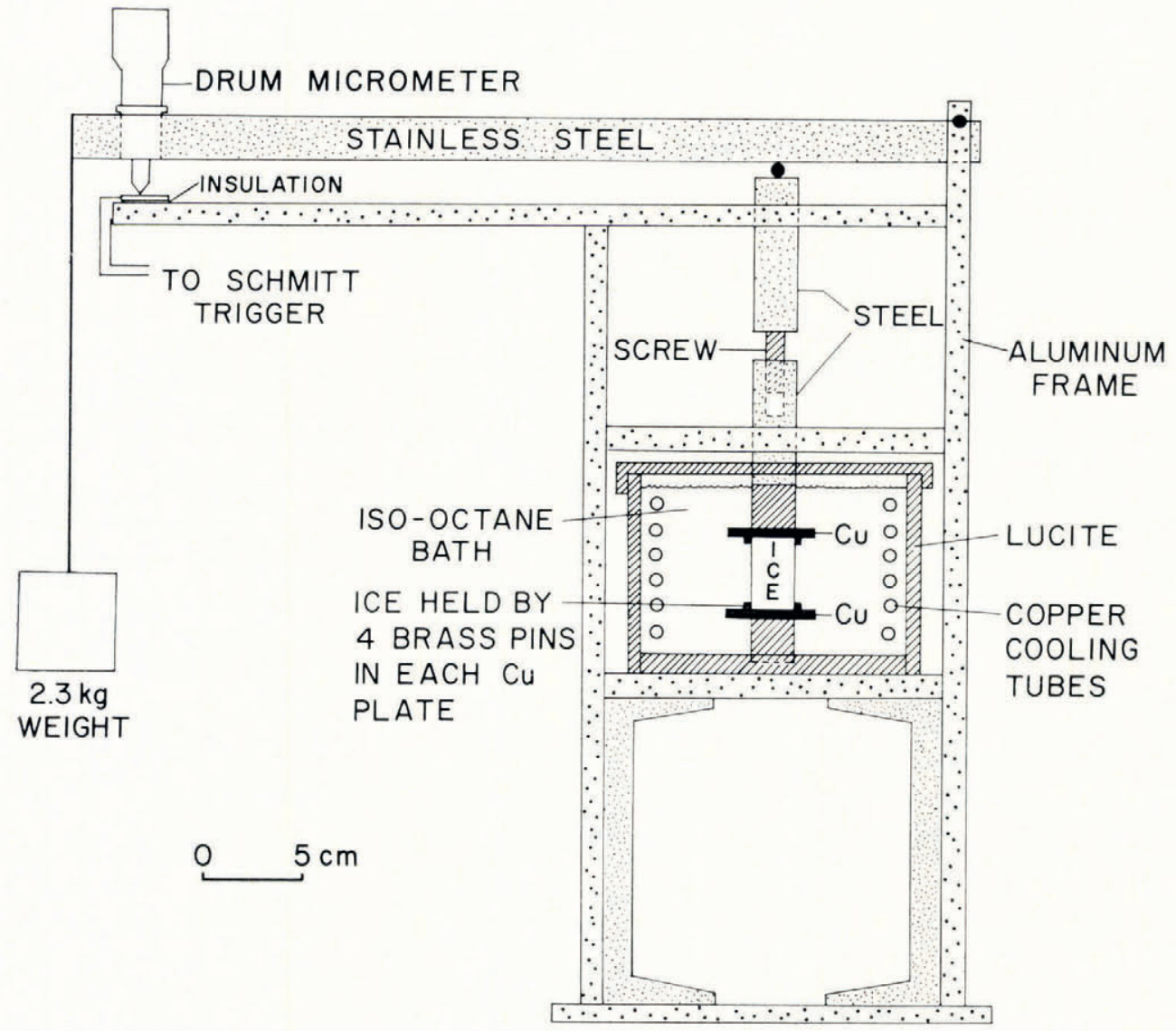

Fig. I. Schematic diagram of apparatus used in experiments.

TABle I. SUmmary OF EXPERIMENTAL RESUlts

\begin{tabular}{|c|c|c|c|c|c|c|c|c|c|c|}
\hline \multirow[b]{3}{*}{ Run } & \multirow{3}{*}{$\begin{array}{l}\text { Volume } \\
\text { fraction } \\
\text { of sand }\end{array}$} & \multirow[b]{3}{*}{$\begin{array}{c}\lambda-d \\
\mathrm{~mm}\end{array}$} & \multicolumn{3}{|c|}{$\begin{array}{c}\text { Time interval over } \\
\text { which creep rate } \\
\text { determined }\end{array}$} & \multirow{3}{*}{$\begin{array}{l}\text { Normalized } \\
\text { strain-rate } \\
\text { year }^{-1}\end{array}$} & \multirow{3}{*}{$\begin{array}{l}\text { Initial } \\
\text { sample } \\
\text { length } \\
\mathrm{mm}\end{array}$} & \multirow{3}{*}{$\begin{array}{c}\text { Yield } \\
\text { strength } \\
\sigma_{\mathbf{y}}=B / \alpha \\
\alpha=2 \\
\text { bar }\end{array}$} & \multirow{2}{*}{\multicolumn{2}{|c|}{$\begin{array}{c}\text { Temperature during } \\
\text { measurement } \\
\text { interval }\end{array}$}} \\
\hline & & & Actual & $\begin{array}{l}\text { start, } \\
\text { hours } \\
\text { from } \\
\text { beginning }\end{array}$ & & & & & & \\
\hline & & & $\begin{array}{l}\text { stress } \\
\text { bar }\end{array}$ & $\begin{array}{c}\text { of run } \\
\mathrm{h}\end{array}$ & $\begin{array}{l}\text { Duration } \\
\mathrm{h}\end{array}$ & & & & $\begin{array}{c}\text { Mean } \\
{ }^{\circ} \mathrm{C}\end{array}$ & $\begin{array}{l}\text { Range } \\
\text { deg }\end{array}$ \\
\hline $1 \dagger$ & 0 & - & 6.4 & 12 & 13 & 0.95 & 29 & 2.8 & -7.4 & 0.3 \\
\hline $3^{*}$ & o & 一 & 5.8 & 23 & 32 & 0.80 & 35 & 3.0 & -8.6 & 0.4 \\
\hline 4 & o & - & 5.8 & 39 & 18 & 0.92 & 32 & 2.9 & $-9 \cdot I$ & 0.2 \\
\hline 5 & 0.053 & 0.16 & $5 \cdot 3$ & 40 & 24 & $0.5^{8}$ & $3^{8}$ & $3 \cdot 3$ & -9.2 & 0.1 \\
\hline 6 & 0.098 & 0.12 & 5.5 & 21 & $3 \mathrm{i}$ & 0.27 & $3^{2}$ & 4.2 & -9.0 & O.I \\
\hline 7 & 0.096 & 0.12 & 5.8 & 77 & IO & 0.37 & 27 & 3.8 & -8.9 & 0.2 \\
\hline 8 & o.1 46 & 0.094 & 6.0 & 20 & 60 & 0.22 & 29 & 4.5 & $-9 . \mathrm{I}$ & 0.5 \\
\hline 9 & 0.220 & 0.073 & $5 \cdot 5$ & $3^{2}$ & 45 & O. I I & $3^{2}$ & 5.6 & $-9 \cdot 1$ & 0.4 \\
\hline 10 & 0.347 & 0.054 & $5 \cdot 4$ & $3^{1}$ & 45 & 0.047 & $3^{I}$ & $7 \cdot 3$ & $-9 . \mathrm{I}$ & 0.1 \\
\hline I I & 0.021 & 0.24 & $5 \cdot 4$ & $3 I$ & 38 & $\mathrm{I} .4 \mathrm{O}$ & 24 & 2.5 & -9.2 & 0.4 \\
\hline 12 & 0.066 & 0.14 & $5 \cdot 3$ & 60 & 28 & 0.84 & 29 & 3.0 & -9.0 & 0.2 \\
\hline 13 & 0.013 & 0.29 & $5 \cdot 5$ & 70 & I 6 & $0.7 \mathrm{I}$ & 27 & 3.1 & -8.9 & 0.3 \\
\hline $13+$ & - & - & - & 209 & 55 & 0.97 & - & 2.8 & $-9 \cdot \mathrm{I}$ & O. I \\
\hline
\end{tabular}


and stainless steel piston have different coefficients of thermal expansion, random changes in room temperature resulted in a random error which reduced the final accuracy of measurement on the samples to about $\pm 2 \mu \mathrm{m}$.

Samples were prepared by placing a porous mixture of natural snow and sand in a thickwalled lucite cylinder, $1.95 \mathrm{~cm}$ in diameter and $10 \mathrm{~cm}$ long, de-aerating the cylinder, and then admitting de-aerated water at $0^{\circ} \mathrm{C}$. Samples were virtually free of air bubbles and appeared to have a uniform distribution of sand. A $3 \mathrm{~cm}$ section was cut from the most uniform part of the sample, and ends of this section were carefully faced perpendicular to the axis of the sample. The sample diameter was measured at eight to twelve points with a micrometer which could be read to $\pm \mathrm{I} \mu \mathrm{m}$. The sample length was measured with a steel tape to the nearest $0.2 \mathrm{~mm}$. After the compression test, the sample was cut in half, and sediment concentrations in the two halves were determined independently by melting the ice and weighing the sand residue. Sand concentrations were reduced to volume percent sand assuming a density of $0.9 \mathrm{Mg} / \mathrm{m}^{3}$ for ice and $2.7 \mathrm{Mg} / \mathrm{m}^{3}$ for sand. Sand concentrations in the two halves of the same sample varied by less than $10 \%$ of the amount present. In thin sections cut from the samples, $c$-axis orientations appeared to be random, and ice crystals averaged $300 \mu \mathrm{m}$ to $500 \mu \mathrm{m}$ in diameter.

The sand recovered from the samples was combined and sieved after all tests had been completed. The geometric mean grain size was $\mathrm{r} 80 \mu \mathrm{m}$, and the geometric standard deviation was I.57. The sieve data were used to estimate the number of particles in a cubic millimeter of sand without pore space ( $\left.175^{\circ}\right)$, the average particle diameter $(64 \mu \mathrm{m})$, and the diameter of the particle with the average volume ( $102 \mu \mathrm{m})$.

During a test, the drum micrometer, bath temperature, and room temperature were read at intervals of one to three or four hours from early morning to late evening. There was usually a gap of 6 to $8 \mathrm{~h}$ in the readings between about midnight and $6 \mathrm{a} . \mathrm{m}$. Total strain versus time curves were plotted (Fig. 2), and the slope of the curve in the region of secondary creep was determined by least-squares methods. The time interval used for this calculation generally started more than $20 \mathrm{~h}$ after stress was applied, thus allowing for transient creep. This time interval usually lasted more than $20 \mathrm{~h}$, and included no systematic changes in bath temperature (Table I).

Weertman (I969) suggested that it is necessary to obtain the creep rate over a total strain of approximately 10\% to be sure that transient creep is not contributing to the observed strain rate. In the present experiments the total strain was on the order of $\mathrm{I} \%$, so some transient creep may be included. To test for this, a least-squares procedure was used to fit a curve

$$
\epsilon=\epsilon_{0}+\beta t^{1 / 3}+\kappa t
$$

(Glen, I955, p. 530) to the total strain versus time curve over the time interval defined above. In this equation $\beta$ is the transient creep rate, $\kappa$ is the secondary creep rate, $\epsilon_{0}$ is a constant resulting from the curve-fitting procedure, $\epsilon$ is the total strain, and $t$ is time since the beginning of the run. In general the secondary creep rate determined by this method differed from the slope of a straight line through the data by less than 0.02 year $^{-1}$. Furthermore, in a few instances the creep rate increased slightly over the time interval involved, resulting in a positive $\beta$. Therefore it is assumed that the slope of a straight line through the data provides an accurate measure of the secondary creep rate.

Because there were slight differences in temperature and stress between runs, all strainrates were normalized to a stress of $5.6 \mathrm{bar}$ and a temperature of $-9 \cdot \mathrm{I}^{\circ} \mathrm{C}(263.06 \mathrm{~K})$ by the use of the relationship

$$
\dot{\epsilon}_{\mathrm{n}}=\dot{\epsilon}\left(\frac{5 \cdot 6}{\sigma}\right)^{3.2} \exp \left[\frac{Q}{R}\left(\frac{\mathrm{I}}{T}-\frac{\mathrm{I}}{263.06}\right)\right]
$$


which is based on Glen's flow law and the Arrhenius equation (Glen, 1955). $\dot{\epsilon}_{\mathrm{n}}$ is the normalized secondary creep rate, $\dot{\epsilon}, \sigma$, and $T$ are the observed strain rate, stress, and temperature in kelvins during the run, $Q$ is the effective activation energy for creep, $R$ is the gas constant, and the value of the exponent, 3.2, is that determined by Glen (1955) in similar uniaxial tests on fine-grained ice.

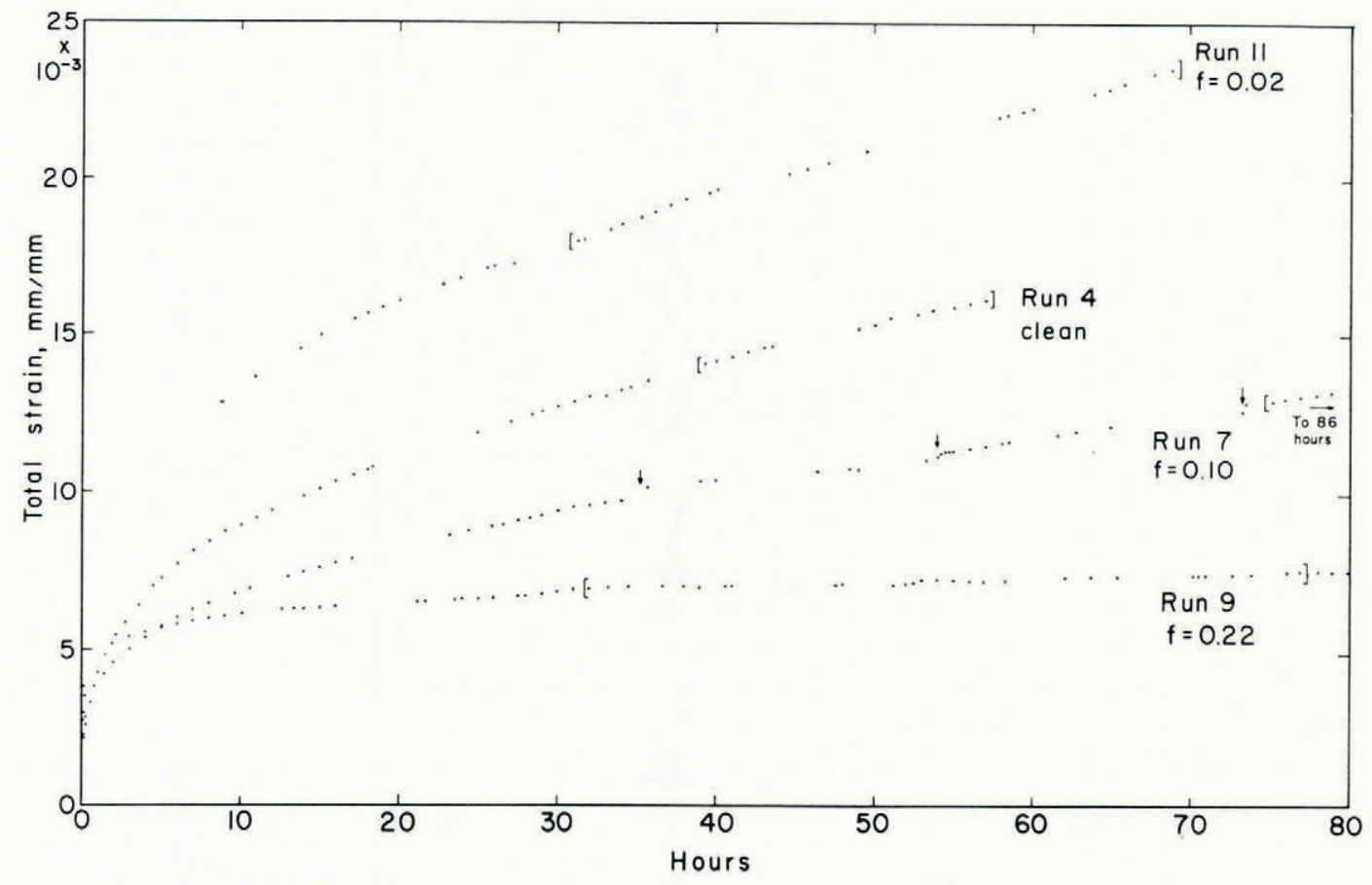

Fig. 2. Representative total strain versus time curves. Each dot represents a separate measurement of total strain. Brackets indicate part of curve used for calculation of secondary creep rate. Arrows on curve for run 7 indicate times when iso-octane was added to the bath (Fig. I). Loss of iso-octane was a serious problem only during this run.

Mellor and Testa (1969, p. I35, I4I) have shown that the Arrhenius equation is invalid above $-10^{\circ} \mathrm{G}$, possibly because the creep rate is increased by grain-boundary melting. However for small changes in $\mathrm{I} / T$, an equation of the form of the Arrhenius equation can be used to estimate the change in $\dot{\epsilon}$ if the true activation energy is replaced by a somewhat higher effective activation energy. The effective activation energy at $-9^{\circ} \mathrm{C}$ was determined graphically from figure 3 of Mellor and Testa (r969) and is about $87.6 \mathrm{~kJ} / \mathrm{mol}$. The temperature normalization generally changed the creep rate by less than 0.02 year $^{-1}$ so results are not sensitive to the exact value of $Q$ used.

\section{Results}

Results of the experiments are presented in Figure 3. The first three tests were done on clean ice. Run I was too short; hence the large error bar. During run 3 there were some unexplained discontinuities in the total strain versus time curve, so the strain rate obtained from this run is not as reliable as that from run 4.

Mellor and Testa ( 1969 ) ran a sample of clean ice at i i .8 bar and $-9.9^{\circ} \mathrm{C}$, and Goughnour and Andersland ( 1968 ) ran one at 6.8 bar and $-7.6^{\circ} \mathrm{C}$. When normalized to 5.6 bar and $-9 . \mathrm{I}^{\circ} \mathrm{C}$ with the use of Equation (2), these runs give strain rates of 0.94 year $^{-1}$ and $\mathrm{r} .00$ 
year $^{-1}$ respectively. These strain rates are not significantly higher than our strain rates on clean ice (Fig. 3). Thus our procedure gives reasonably reproducible results which are consistent with results obtained by others.

Creep rates measured on ice with low sand concentrations scatter somewhat more than expected. Particularly surprising was an abrupt increase in creep rate after about $206 \mathrm{~h}$ in run ${ }_{3} 3$ (Table I). These results suggest that the creep rate of ice with low sand concentrations is sensitive to factors which were not closely controlled during the experiments. Among these factors are crystal size, exact size distribution of sand particles, exact spacing of sand particles in the ice, positions of sand particles relative to crystal boundaries, and concentration of chemical impurities in the ice. (See Jones and Glen (1969) for laboratory data on the latter.)

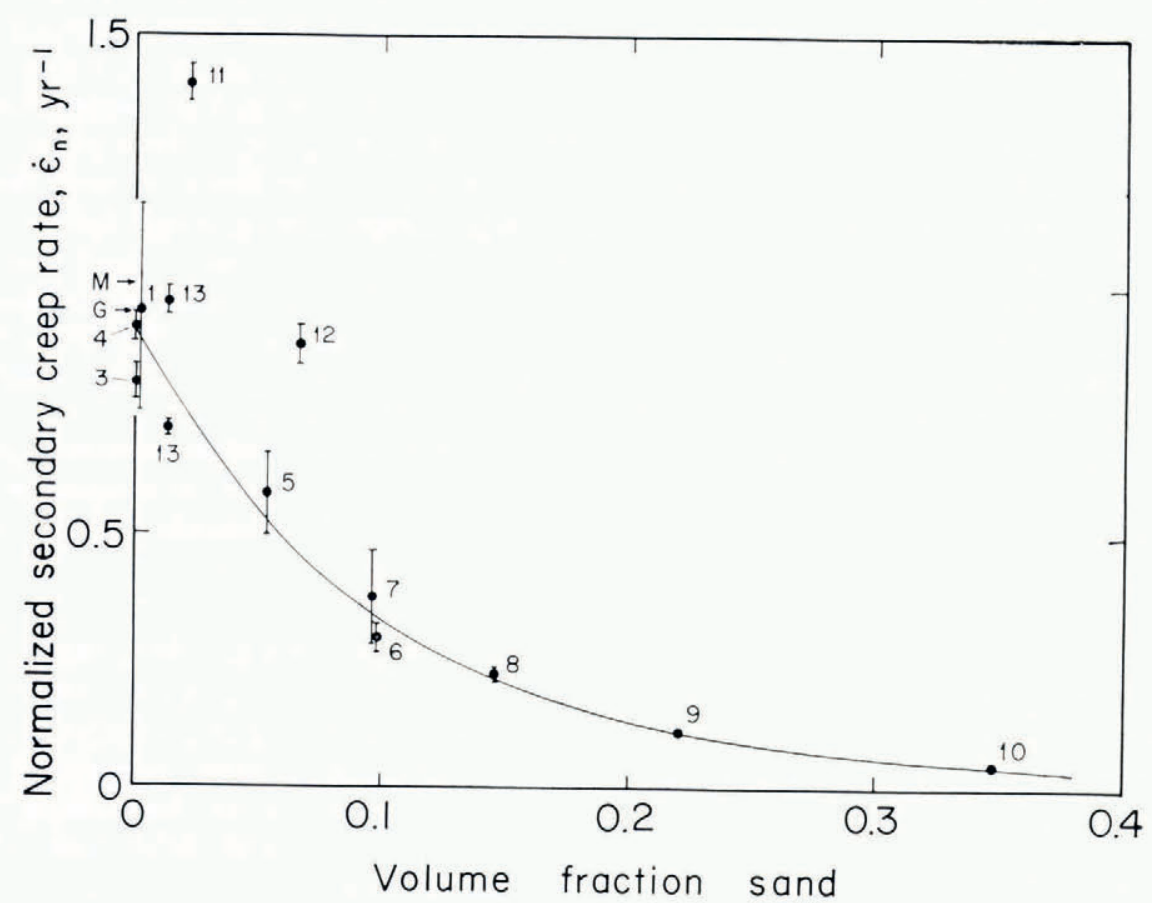

Fig. 3. Results of experiments. Error bars represent $99 \%$ confidence limits on slope of secondary creep curve (Krumbein and Graybill, $1965, p .230)$. Error bars on samples 9 and 10 are smaller than size of dot. Points for clean ice offset horizontally for clarity. $G \rightarrow$ and $M \rightarrow$ : creep rates determined by Goughnour and Andersland (1968) and by Mellor and Testa (1969) normalized to 5.6 bar and $-9.1^{\circ} \mathrm{C}$ (see text).

The high creep rate for ice with 0.02 I volume fraction sand is consistent with qualitative field observations in the TUTO ice tunnel, and with experimental observations of Goughnour and Andersland (r968). Butkovich and Landauer (1959) and Swinzow (r962) found that closure rates in the TUTO tunnel were faster in slightly dirty ice than in clean ice, and slower in very dirty ice than in clean ice. From Butkovich and Landauer's photograph and Swinzow's description of the slightly dirty ice, it is apparently comparable to the banded ice in which Hooke (I970, p. 306) measured sediment concentrations of o.o I to 0.024 volume fraction sand. Goughnour and Andersland ( 1968 ) found that the peak strength of ice with 0.03 volume fraction sand was I $\%$ less than for clean ice. Such a decrease in strength would increase the creep rate. 


\section{Discussion}

The problem of the decrease in creep rate of ice with increasing volume fraction sand is analogous to the problem of dispersion hardening of metals with large $(>\approx I \mu \mathrm{m})$, widely spaced particles which are much harder than the matrix. Orowan (1948) suggested that a dislocation moving through a crystal and encountering one of these particles, would bow around it, close behind it, and pass on, leaving a dislocation loop around the particle. The stress increment $\Delta \sigma$ required to bow a dislocation between adjacent particles is

$$
\Delta \sigma=3 \cdot 5 G b / \lambda
$$

where $G$ is the shear modulus, $b$ the Burgers vector, $\lambda$ the distance between particle centers, and $\Delta \sigma$ the difference between the stress required to bow a dislocation between two particles and that required to move a dislocation through the pure matrix. The right side of the equation has been multiplied by $\sqrt{ } 3$ to express the result in terms of the normal stress, rather than the shear stress (Nye, I953, p. 486). For large particles $\lambda$ should be replaced by $\lambda-d$ where $d$ is the particle diameter (Meiklejohn and Skoda, I96o, p. 775). In ice $G=3 \times 1^{10}$ $\operatorname{dyn} / \mathrm{cm}^{2}\left(3 \times \mathrm{IO}^{9} \mathrm{~N} / \mathrm{m}^{2}\right)$ (Weertman, $\left.\mathrm{I} 963\right)$ and $b=4.5 \times 10^{-10} \mathrm{~m}$ (Kuroiwa and Hamilton, I 963 , p. 44), so for $\lambda-d$ on the order of o. I mm (Table I) Equation (3) yields $\Delta \sigma=0.24$ bar.

The Orowan stress is the stress required to bow the first dislocation that reaches the particles. As dislocation loops accumulate around a particle, the critical stress required to bow each subsequent loop increases, thus resulting in work hardening. The stress increases until the inner loop is able to bypass the particle by dislocation climb. At this time steadystate or secondary creep begins (Hart, in press; McLean, i962, p. 312, 32 I).

In the case of ice we take the yield strength to be proportional to the parameter $B$ in Glen's (1955) flow law, $\dot{\epsilon}=(\sigma / B)^{n}$, because $\dot{\epsilon}$ is small when the normal stress $\sigma$ is appreciably less than $B$ and increases rapidly as $\sigma$ increases above $B$. Rewriting we obtain

$$
B=\sigma / \dot{\epsilon}^{1 / n}=\alpha \sigma_{\mathrm{y}}
$$

where $\sigma_{\mathrm{y}}$ is the yield strength and $\alpha$ is a constant of proportionality. In clean ice at the pressure melting point the yield strength is about I bar (Nye, I95 I, p. 559), and $B$ is about 2 bar year ${ }^{1 / n}$ (Glen, I955), so $\alpha$ is approximately 2 year $^{1 / n}$. Experimental values of $\sigma_{\mathbf{y}}$ (Table I) are calculated assuming a value of 3.2 for $n$. The increase in yield strength due to the dispersed particles, $\left(\sigma_{\mathrm{y}}-\sigma_{\mathrm{ym}}\right)$, is typically I to 2 bars, where $\sigma_{\mathrm{ym}}$ is the yield strength of the pure matrix (runs I, 3, and 4). As expected, these values are substantially larger than the stress increment $\Delta \sigma$ required to bow the first dislocation loop.

A metallurgical study which is comparable to ours in terms of temperature (relative to the melting point) and particle size was conducted by Meiklejohn and Skoda (1960), who studied the effect of $\mathrm{Fe}$ particles, 50 to $770 \mu \mathrm{m}$ in diameter, on the strength of $\mathrm{Hg}$ at $77 \mathrm{~K}$. They found as did we, that $\left(\sigma_{\mathrm{y}}-\sigma_{\mathrm{ym}}\right)$ increased linearly with $\mathrm{I} /(\lambda-d)$. However, the rate of increase varied with particle size, which is contrary to the prediction of the Orowan model. Meiklejohn and Skoda concluded that $\left(\sigma_{\mathbf{y}}-\sigma_{\mathrm{ym}}\right)$ was primarily a function of the volume fraction of $\mathrm{Fe}$ in the $\mathrm{Hg}$. Recent theoretical analyses of work hardening by Ashby (r966, 1970) and Hart (in press) reach the same conclusion.

Hart considers the work hardening resulting from the accumulation of a number of Orowan dislocation loops around each particle. These loops produce an ordered back-stress field which inhibits passage of normal glide dislocations. Hart's theory predicts

$$
\sigma_{\mathbf{y}}-\sigma_{\mathbf{y m}}=3.9 G f(b a / d)^{1 / 2}
$$

where $a$ is the total strain, $f$ is the volume fraction of impurities, and the coefficient has been adjusted to give the result in terms of normal stress and strain rather than unresolved shear 
stress (Nye, 1953, p. 487). We will take $a$ to be the total strain at which secondary creep begins, or about o.or. Substituting appropriate values for ice then yields:

$$
\sigma_{\mathbf{y}}-\sigma_{\mathbf{y m}}=25 f \text { bar. }
$$

Graphically $B$ does increase linearly with $f$ for $f>0.05$, but the slope of the line is 14 rather than 25. Thus Hart's model overestimates the influence of sand on the creep of ice.

Ashby (1966, I970) suggested that secondary slip occurs around each particle as the matrix undergoes shear deformation. As a result, secondary dislocation loops are generated at the particle-matrix interface and migrate outward, eventually forming a dense tangle of dislocations around the particle. The tangle inhibits normal movement of primary glide dislocations past the particle, and is thus responsible for decreasing the creep rate. For application to the present experiments, this model is conceptually better than the Orowan model because $\lambda-d$ is comparable to the ice crystal diameter. Thus sand grains are likely to be on crystal boundaries, and dislocations moving through crystals are not likely to form loops around the sand grains. If we assume that recovery effects are negligible during transient creep, we can use Ashby's (1970, equation (4.4)) model to estimate an upper bound for $\left(\sigma_{\mathbf{y}}-\sigma_{\mathbf{y m}}\right)$. The appropriate equation in the notation used in this paper is

$$
\sigma_{\mathrm{y}}-\sigma_{\mathrm{ym}}=2.3 G(b f a / d)^{\mathrm{I} / 2}=\mathrm{I} 4.6 \sqrt{ } f \text { bar. }
$$

For comparison the inclined line in Figure 4 has a slope of about 12. In view of the uncertainties in the theories (oral communication from M. F. Ashby, November 197I) and the assumptions made in their application to the present problem, the close agreement between theory and experiment is in part fortuitous. Agreement within a factor of 2 would be acceptable.

The Orowan, Hart, and Ashby theories all assume that the matrix is well below the melting point so that recovery effects such as dislocation climb and cross slip may be neglected. Furthermore these theories deal with particles which are an order of magnitude smaller and

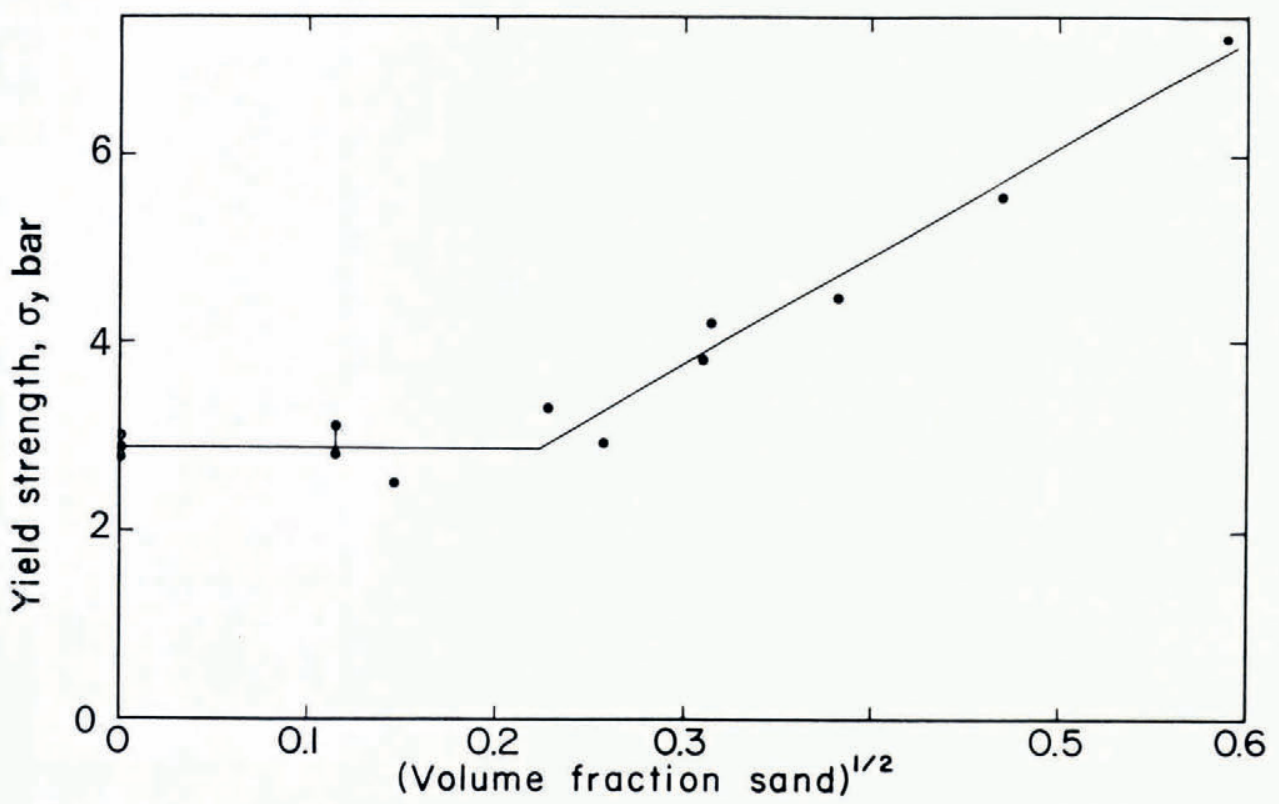

Fig. 4. Relationship between yield strength $\left(\sigma_{\mathrm{y}}=\sigma / 2 \dot{\epsilon}^{\mathrm{T} / n}\right.$ with $\left.n=3.2\right)$ and square root of volume fraction sand. Two creep rates observed during run $I_{3}$ are connected by vertical line. 
closer together than those with which we are concerned (personal communication from E. W. Hart, July I97I). For these reasons some metallurgists have questioned the applicability of the theories to the present problem.

An alternative approach might be to consider the ice as a non-Newtonian viscous fluid containing solid spheres. However this procedure has disadvantages on conceptual as well as practical grounds. Conceptually, in contrast to the situation in a fluid, ice is a crystalline substance deforming by dislocation glide and climb mechanisms, and the sand particles are tightly bound to the matrix. Practically, theories of flow of Newtonian fluids with solid inclusions (Nielsen, 1967) underestimate the effect of sand on the creep of ice by about an order of magnitude, and the authors are not aware of any treatments of the non-Newtonian problem.

\section{Concluding statement}

Ashby (1966, 1970) and Hart (in press) both suggest that each particle in a dispersionhardened metal is surrounded by a tangle of dislocations which impedes movement of primary glide dislocations. The differences between the theories are due to differences in the presumed origin of dislocations in the tangle; Ashby assumes that they were generated at the particlematrix interface, whereas Hart assumes that they moved to the particle and were trapped by it. The general agreement between our observations and the predictions of these theories

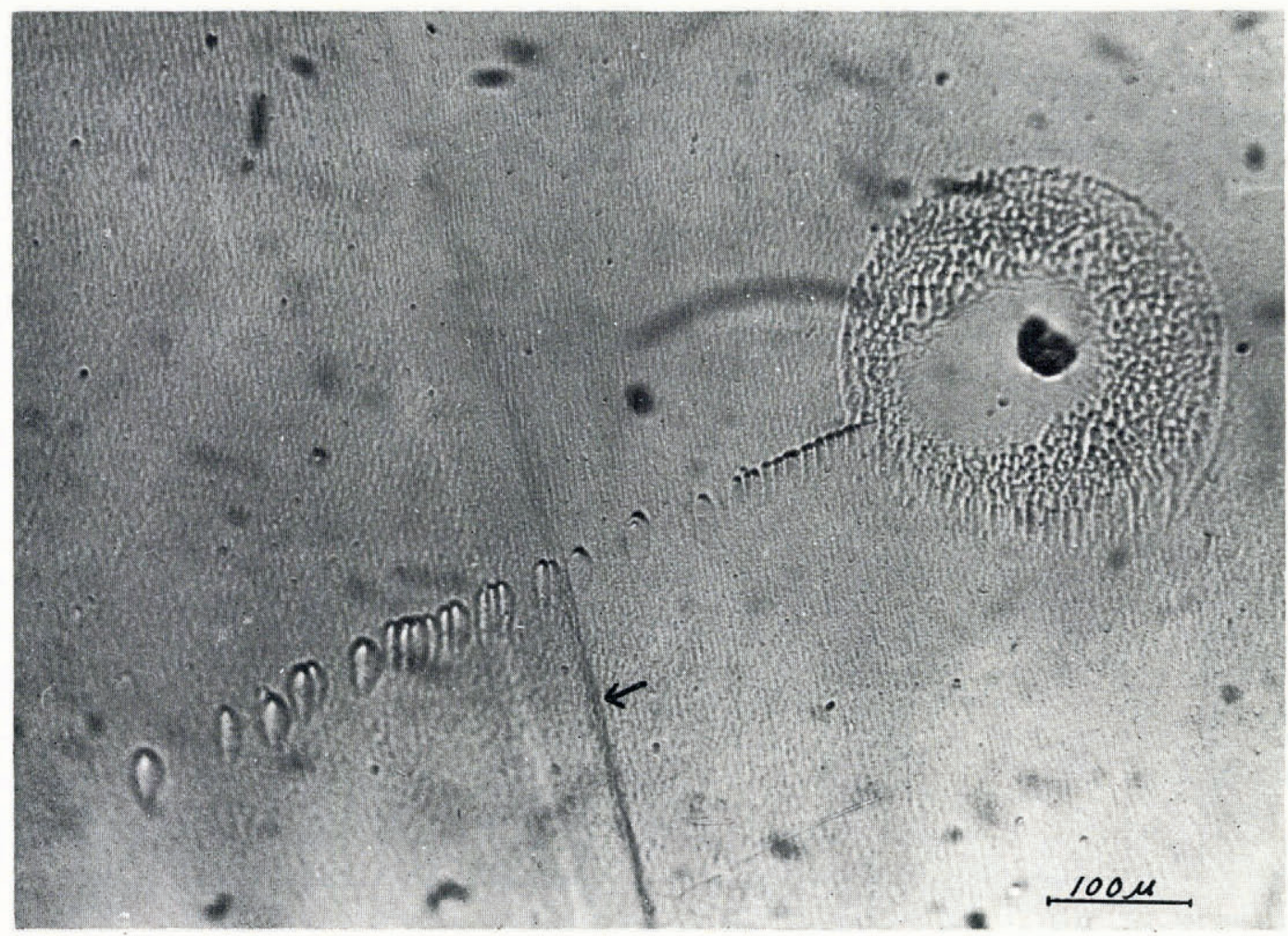

Fig. 5. Sand grain in Mendenhall glacier ice surrounded by cloud of dislocation etch pits. Row of etch pits running diagonally across figure suggests that sand grain acts as source for dislocations. Pholograph by Kuroiwa and Hamilton (1963, p. 54). Copyright by M.I.T. Press; reproduced with permission. 
suggests that sand grains in deforming ice may also be surrounded by clouds of dislocations which impede passage of primary glide dislocations. Kuroiwa and Hamilton (1963) found that a sand grain in Mendenhall glacier ice was surrounded by such a cloud (Fig. 5).

If we assume that each sand grain is at the center of an hypothetical rigid sphere of ice, while ice outside these spheres deforms normally, the diameters of the rigid spheres can be calculated. For ice with 0.05 to 0.15 volume fraction sand this diameter is on the order of twice the diameter of the included sand particle, or about $200 \mu \mathrm{m}$. At higher volume fractions the diameter decreases, perhaps reflecting overlap of the spheres of influence of adjacent particles. This diameter is comparable to the diameter of the cloud in Figure 5 , but the particle in Figure 5 is substantially smaller than our average particle.

The erratic results of experiments with low sand concentrations may indicate the existence of processes which tend to increase the creep rate. For instance sand may decrease the ice crystal size (Hooke, I970, p. 316), thus promoting grain boundary slip (McLean, I962, p. 307), or individual sand grains may act as sources for primary dislocations. D. F. Stein (oral communication, May r97I) suggested that the line of dislocation etch pits running diagonally across Figure 5 indicates that the sand grain is acting as such a source. The increase in spacing of the etch pits is due to elimination of adjacent dislocations of opposite sign as the dislocations move outward from the source.

\section{Acknowledgements}

D. F. Stein, formerly of the Metallurgy Department at the University of Minnesota, directed us to pertinent references in metallurgy and gave valuable suggestions during preparation of the manuscript. M. F. Ashby, E. W. Hart, and J. Weertman kindly reviewed the manuscript. D. Kuroiwa contributed the photograph in Figure 5. The Neslab temperature bath was loaned for the study by R. F. Roy. V. R. Murthy, E. C. Perry, and F. M. Swain also loaned essential laboratory equipment. The study was supported financially by the National Science Foundation.

$M S$. received 30 June $197 \mathrm{I}$ and in revised form 6 December $197 \mathrm{I}$

\section{REFERENGES}

Ashby, M. F. 1966. Work hardening of dispersion-hardened crystals. Philosophical Magazine, Eighth Ser., Vol. I4, No. 132, p. I $157-78$.

Ashby, M. F. 1970. The mechanical effects of a dispersion of a second phase. Division of Engineering and Applied Physics, Harvard University. Technical Report No. 3 .

Butkovich, T. R., and Landauer, J. K. 1959. A grid technique for measuring ice tunnel deformation. Fournal of Glaciology, Vol. 3, No. 26, p. 508-I I.

Glen, J. W. I955. The creep of polycrystalline ice. Proceedings of the Royal Society, Ser. A, Vol. 228, No. I I 75, p. 5 19-38.

Goughnour, R. R., and Andersland, O. B. 1968. Mechanical properties of a sand-ice system. Journal of the Soil Mechanics and Foundations Division, American Society of Civil Engineers, Vol. 94, No. SM4, p. 923-5o.

Hansen, B. L., and Langway, C. C., jr. I966. Deep core drilling in ice and core analysis at Camp Century, Greenland, 1961-1966. Antarctic Fournal of the United States, Vol. I, No. 5, p. 207-08.

Hart, E. W. In press. Theory of dispersion hardening in metals. Acta Metallurgica.

Hooke, R. L. 1970. Morphology of the ice-sheet margin near Thule, Greenland. Fournal of Glaciology, Vol. 9, No. 57, p. 303-24.

Jones, S. J., and Glen, J. W. I969. The effect of dissolved impurities on the mechanical properties of ice crystals. Philosophical Magazine, Eighth Ser., Vol. 19, No. I57, p. I $3-24$.

Krumbein, W. C., and Graybill, F. A. I965. An introduction to statistical models in geology. New York, McGraw-Hill.

Kuroiwa, D., and Hamilton, W. L. 1963 . Studies of ice etching and dislocation etch pits. (In Kingery, W. D., ed. Ice and snow; properties, processes, and applications: proceedings of a conference held at the Massachusetts Institute of Technology, February $12-16,1962$. Cambridge, Mass., M.I.T. Press, p. 34-55.)

McLean, D. I962. Mechanical properties of metals. New York, John Wiley.

Meiklejohn, W. H., and Skoda, R. E. 1960. Dispersion hardening. Acta Metallurgica, Vol. 8, No. I I, p. $773-80$. 
Mellor, M., and Testa, R. 1969. Effect of temperature on the creep of ice. Fournal of Glaciology, Vol. 8, No. 52, p. $13 \mathrm{I}-45$.

Nielsen, L. E. 1967. Mechanical properties of particulate-filled systems. Fournal of Composite Materials, Vol. 1, No. I, p. 100-19.

Nye, J. F. 1951. The flow of glaciers and ice-sheets as a problem in plasticity. Proceedings of the Royal Society, Ser. A, Vol. 207, No. 1091, p. 554-72.

Nye, J. F. 1953. The flow law of ice from measurements in glacier tunnels, laboratory experiments and the Jungfraufirn borehole experiment. Proceedings of the Royal Society, Ser. A, Vol. 219, No. 1 I39, p. 477-89.

Orowan, E. 1948. Discussion. (In Symposium on internal stresses in metals and alloys. Organized by the Institute of Metals .... and held in London, . . . I 5 th and 16 th October 1947. London, Institute of Metals, p. 451-53. (Institute of Metals Monograph and Report Series, No. 5.))

Schmitt, O. H. 1938. A thermionic trigger. Fournal of Scientific Instruments, Vol. 15, No. 1, p. $24-26$.

Swinzow, G. K. I962. Investigation of shear zones in the ice sheet margin, Thule area, Greenland. Fournal of Glaciology, Vol. 4, No. 32, p. 215-29.

Weertman, J. 1963. The Eshelby-Schoeck viscous dislocation damping mechanism applied to the steady-state creep of ice. (In Kingery, W. D., ed. Ice and snow; properties, processes, and applications: proceedings of a conference held at the Massachusetts Institute of Technology, February $12-16,1962$. Cambridge, Mass., M.I.T. Press, p. 28-33.)

Weertman, J. 1969. The stress dependence of the secondary creep rate at low stresses. Fournal of Glaciology, Vol. 8, No. 54, p. 494-95. [Letter.] 